\title{
Globalizācijas ietekme uz līgumsoda piemērošanu
}

\author{
Zane Rinmane \\ Rìgas Stradina universitāte, \\ Juridiskā fakultāte, Latvija \\ zane.rinmane@gmail.com
}

\section{Kopsavilkums}

Rakstā sniegts ieskats līgumsoda būtības izpētē. Publikācijas mērḳis ir iepazīstināt ar pētỉjumu par līgumsoda institūtu globālā kontekstā un atklāt problēmas, kas mūsdienu tiesiskajā vidē rodas, to piemērojot. Līgumsoda institūtu pētot, par prioritāru tika izvirzìta tā samērīguma principa ievērošanas problemātika kā nacionālā, tā arī globālā mērogā. Rakstā tiek salīdzināta līgumsoda izpratne dažādās tiesību sistēmās un globalizācijas ietekme uz līgumsoda institūtu Latvijas Republikā.

Atslēgvārdi: līgumsods, iepriekš novērtēto zaudējumu atlīdzināšana.

\section{levads}

Pētot saistību tiesību attīstību, tika novērota tendence virzìties uz šo tiesību starptautisko unifikāciju un harmonizāciju. Piemēram, dạ̣a Eiropas valstu ir pārstāvēta kontinentālās Eiropas tiesību sistēma, bet citā daḷā - anglosakšu tiesību sistēma.

Līgumsods ir tiesību institūts, par kuru izpratne abās šajās tiesību sistēmās kardināli atškiras. Anglosakšu tiesībās kategoriski netiek atzīts jēdziens "līgumsods". Tiek uzskatīts, ka privāttiesības nevar saistìt ar sodīšanu, taču minētais ir pavisam normāls tiesību institūts kontinentālās Eiropas tiesībās.

Viskarstākie strīdi ir tieši par līgumsoda samērīguma jautājumiem, tādēl Latvijā likumdevējs veicis apjomīgus un būtiskus grozījumus Civillikumā līgumsoda kontekstā. Saistībā ar šiem 2013. gada 20. jūnija grozījumiem Civillikumā būtiski tika ietekmēta Latvijas tiesu prakse un liela dạ̧a Senāta tēžu zaudēja aktualitāti.

Lìgumsodu samērīgums ir galvenais strīdu jautājums ne vien Latvijas, bet arī globālajās tiesībās, tomēr tas nav vienīgais. Daudz ir citu problēmjautājumu, tostarp par 
līgumsoda piemērošanu. Kā noteikt saistības vērtību beztermina līgumā? Kā noškirt saistības neizpildi vispār no saistības nepienācīgas izpildes vai neizpildīšanas noteiktā laikā? Kā noteikt galveno saistību (pamatparādu)?

Rakstā analizēti arī aktuālākie Eiropas Kopienu Tiesu prakses problēmjautājumi un izpratne par līgumsoda institūta funkcijām dažādu valstu tiesību harmonizācijas kontekstā. Pievērsta arī uzmanība tam, ka pēdējā laikā saistībā ar pētāmajiem jautājumiem judikatūra mainās arī anglosakšu tiesību saimes valstīs.

Darba mērḳis ir pētīt līgumsoda institūtu pasaulē un atklāt tā piemērošanas problēmas mūsdienu tiesiskajā vidē. Pētỉjumā tika izmantotas šādas metodes: analītiskā metode - lai analizētu tiesību normas, tiesu praksi, dažādu autoru viedokḷ us un atziņas; salīdzinošā metode - lai salīdzinātu dažādu pasaules valstu tiesību normas līgumsoda kontekstā un atspogulotu dažādu tiesību saimju izpratni par līgumsodu; vēsturiskā metode - lai sniegtu ieskatu par līgumsoda evolūciju Latvijā.

\section{Līgumsoda evolūcija Latvijā līdz mūsdienām}

Līgumsods - tāpat kā galvojums, hipotēka un rokasnauda - ir viens no visplašāk izmantotajiem saistību tiesību pastiprināšanas veidiem Latvijas Republikā. Šis tiesību institūts Latvijā pastāv jau kopš laika, kad Latvija vēl bija cariskās Krievijas sastāvdal̦a [35, 137]. Mūsdienās līgumsoda institūtu reglamentē Civillikuma (turpmāk - CL) 1716.1724. ${ }^{1}$ pants [1]. Lìgumsods ir mantisks samazinājums, ko kāda persona uzṇemas ciest, ja nepildīs vai nepienācīgi pildīs līgumsaistìbas. Līgumsodu var noteikt gan naudā, gan kādā citā vērtībā. Ikvienā līgumā var tikt paredzēts līgumsods, un pēc būtības tas pastāv kā galvenajai saistībai pakārtota saistība, jo tās izpildỉjums ir tiešā veidā atkarīgs no galvenās saistības pārkāpšanas.

Turpmāk - īss ieskats līgumsoda evolūcijā Latvijas Republikā līdz mūsdienām. Tiesību pētnieks Viktors Brīvmanis savā 1939. gada referātā "Līgumsods" norādīja, ka kreditori jau cariskās Krievijas laikā ar neproporcionāli augstiem un pieaugošiem līgumsodiem, kam nebija nekādu ierobežojumu, šo tiesību institūtu faktiski izmantoja kā peḷnas gūšanas avotu, nevis citas saistības nodrošināšanai [23, 7-8]. Acīmredzams, ka šì problēma Latvijas tiesībās bija aktuāla līdz pat Civillikuma grozījumiem 2013. gada 20. jūnijā.

Pretstatā iepriekš aprakstītajam jāpiemin padomju gadu līgumsodi privātajā sektorā, kas tolaik bija ārkārtīgi šaurs valdošās ideologijas dēḷ. Padomju laikā nebija pat iedomājams par parāda neatdošanu noteikt līgumsodu 0,5\% apmērā. Šāds līgumsods, visticamāk, tiktu kvalificēts kā bezstrādes ienākumu gūšana, par ko draudētu mantas konfiskācija [34]. Tādējādi var secināt, ka padomju varas gadi garajā līgumsoda evolūcijas periodā bija vienīgais laiks, kad nepastāvēja pārmērīgu līgumsodu problēma. Proti, tur, kur nepastāv tirgus ekonomikas institūts, nav aktuāla arī pārmērīgu līgumsodu problēma.

Pēc Latvijas Republikas neatkarības atjaunošanas, stājoties spēkā atjaunotajam Civillikumam, atkal aktuāla kḷuva arī pārmērīgu līgumsodu problēma. Pagājušā gadsimta 
90. gados tā tika risināta patēēēāju tiesībās, Patērētāju tiesību aizsardzības likumā ietverot normas par pārmērīgu līgumsodu nepieḷaušanu, proti, strīdos par pārmērīgiem līgumsodiem tiesas bieži atsaucās uz Patērētāju tiesību aizsardzības likuma normām [14]. Tomēr arī tolaik neproporcionāla līgumsoda lielums tika atstāts atklāta juridiska jēdziena formā. Ar konkrētu saturu to turpmāk ilgu laiku piepildīja tiesu prakse [33, 14-40]. Savukārt tās likumsakarīgs rezultāts bija likumdevēja 2009. gadā pieñemtie pirmie grozījumi Civillikumā attiecībā uz līgumsodu, proti, 2009. gadā Civillikumā tika ietverts jauns pants - 1724. ${ }^{1}$, kurš reglamentēja līgumsoda cietēja tiesības prasìt tiesai līgumsoda apmēra samazināšanu [1].

Tomēr jākonstatē, ka šì jaunā norma neviennozīmīgi atbilst tiesas pienākumam novērtēt pierādījumus pēc savas iekšèjās pārliecības, kas pamatota ar tiesas sēdē vispusīgi, piln̄igi un objektīvi pārbaudītiem pierādījumiem, vadoties no tiesiskās apzinnas, kas balstìta uz logiikas likumiem, zinātnes atziņām un dzīvē gūtiem novērojumiem, kā to paredz Civilprocesa likuma 97. pants [2]. Jāpievērš uzmanība arī šādam faktam: Augstākās tiesas Senāts jau līdz 2009. gadam bija secinājis, ka tiesai taisnīguma nodrošināšanas nolūkā ir tiesības vērtēt līgumsoda samērīgumu neatkarīgi no tā, vai atbildētājs ir norādījis uz līgumsoda pārmērīgi lielo apmēru. Civillikuma $1724 .{ }^{1}$ pantā tika veikti grozījumi arī 2013. gadā. Ar 2013. gada 20. jūnija grozìjumiem frāze "līgumsoda cietējs var lūgt samazināt" tika aizstāta ar "tiesa samazina", tādējādi agrākā tiesas tiesība kḷuva par tās pienākumu. Saskaṇā ar 2009. gadā Civillikumā pien̦emto $1724 .^{1}$ pantu, analizējot to gramatiski, tiesām nebija ne gluži tiesība, ne gluži pienākums pēc savas iniciatīvas samazināt pārmērīgu līgumsodu, ja pats parādnieks to tieši neprasīja. Tomēr galvenais pēc būtības šis $1724 .{ }^{1}$ panta grozījums neko nemainīja pārmērīgu līgumsodu problēmas risināšanā. Proti, jaunais regulējums nedeva vēlamo rezultātu, jo īpaši n,emot vērā, ka Latvijā saistībā ar pārmērīgu līgumsodu samazināšanas praksi jau diezgan ilgstoši pastāv šāda Eiropas Savienības Tiesas nostādnēm atbilstoša Senāta judikatūra.

Līgumsoda kontekstā īpaši jāuzsver Civillikuma 2013. gada 20. jūnija apjomīgie grozijumi, kas tika veikti situācijas eskalācijas dẹl, ko savukārt izraisīja strauji plaukstošais ātro kredītu izsniegšanas bizness un parādu piedziššnas organizāciju skaita palielinājums.

Galvenās pārmaiṇas līgumsoda institūtā kopš minētajiem grozijjumiem ir šādas:

- līgumsoda iedalïjums pēc tã veida (CL 1716. pants);

- līgumsoda aprobežojums procentuāli pieaugošiem maksājumiem (CL 1716. pants);

- ierobežojums prasīt gan likumiskos procentus, gan līgumsodu pilnā apmērā (CL 1722. pants);

- samērīguma princips (CL 1717. pants);

- tiesas pienākums samazināt līgumsodu (CL 1724. ${ }^{1}$ pants);

- atšķirīga maksājumu ieskaitǐšanas kārtība (CL 1843. pants).

Nav šaubu, ka līgumsoda evolūciju Latvijā ir ietekmējusi globalizācija, kas saistās ar geogrāfisko robežu izzušanu, tādējādi saasinot problēmjautājumus, tostarp par saistību izpildi un līgumsoda piemērošanu. 


\section{Spēkā esošo harmonizācijas aktu ietekme uz līgumsodu}

Pasaulē sastopamas vairākas tiesību sistēmas. Daḷā valstu ir pārstāvēta kontinentālās Eiropas tiesību sistēma, bet citā - anglosakšu tiesību sistēma. Lìgumsoda institūta izpratne abās šajās tiesību sistēmās kardināli atšķiras. Anglosakšu tiesībās kategoriski netiek atzìts jēdziens "līgumsods", jo privāttiesības netiek saistìtas ar sodīšanu. Turpretī kontinentālās Eiropas tiesībās līgumsods ir pavisam normāls tiesību institūts. Turpmāk tiks aplūkoti atsevišḳi saistību tiesību harmonizācijas akti, kam ir ietekme uz līgumsoda izpratni un piemērošanu. Izstrādātos līgumtiesību unificēšanas dokumentus var iedalīt: dokumenti ar juridisko spēku - konvencijas, starptautiskie līgumi, regulas, direktīvas jeb hard law - un dažādi doktrināri dokumenti, rezolūcijas, proti, ieteikuma tiesības jeb soft law [35, 19-26].

Vistradicionālākā metode starptautisko privāttiesību saskaņošanā ir tiesību normu unificēšana, izmantojot konvenciju un starptautisko līgumu, kā arī Eiropas Savienības dokumentu (regulu, direktīvu) saistošo spēku.

Pirmkārt, jāapskata Apvienoto Nāciju Organizācijas 1980. gada 11. aprīḷa Konvencija par starptautiskajiem preču pirkuma un pārdevuma līgumiem [13]. Konvencija līgumslēdzēju pusēm reglamentē tādu tiesiskās aizsardzỉbas līdzekli kā zaudējumu atlīdzināšanu.

Konvencijas 74. pantā tiek definēts, kas tieši uzskatāms par zaudējumiem:

“Zaudējumi, kuri rodas, pusei neievērojot līgumu, sastāv no summas, kura ir vienāda ar tiem zaudējumiem, ieskaitot neiegūto labumu, kuri radušies, otrajai pusei pārkāpjot līgumu. Tādi zaudējumi nedrīkst pārsniegt zaudējumus, kurus līgumu pārkāpusī puse līguma slēgšanas brīdī paredzējusi vai kurus tai vajadzēja paredzēt kā iespējamās sekas līguma pārkāpumam, n,emot vērā apstākḷus, par kuriem viṇa tajā laikā zināja vai par kuriem viṇai vajadzēja zināt." [13]

No šìs definīcijas izriet, ka zaudējumi ir ne vien tiešie zaudējumi, bet arī neiegūtais labums, kas var būt līguma pārkāpuma rezultāts. Tomēr pastāv arī piebilde, ka neiegūtajam labumam līguma slēgšanas brīdī vajadzēja būt tieši un precīzi paredzētam. Tādējādi ir konstatējams, ka Konvencijā iekḷauts anglosakšu tiesībām raksturīgais iepriekš novērtēto zaudējumu atlīdzināšanas (liquidated damages) institūts. Proti, jau līguma slēgšanas brīdī pusēm ir skaidri zināmi par zaudējumiem atlīdzināmās materiālās vērtïbas griesti.

Otrkārt, atsevišḳi jāizceḷ Direktīva 2011/7/ES par maksājumu kavējumu novēršanu komercdarijumos [7]. Pārṇemot konkrētās direktīvas normas, Civillikumā tika ieviests Latvijā jauns tiesību institūts "iepriekš novērtētie zaudējumi" (CL 1668. ${ }^{1}$ pants), kas pēc būtības ir tas pats "līgumsoda" institūts Civillikuma 1716. panta izpratnē. Latvijas tiesībās nevajadzētu ieviest anglosakšu tiesībām raksturīgu institūtu, ja iespējams vajadzību izteikt ar jau pastāvošo, t. i., kontinentālās Eiropas tiesībām raksturīgo līgumsodu.

Treškārt, līgumsoda kontekstā jāpiemin Eiropas Padomes 1993. gada 5. aprīḷa Direktīva 93/13/EEK par negodīgiem noteikumiem patērētāju līgumos [5]. Konkrētāk, - 
Direktīvas par negodīgiem līguma noteikumiem 3. panta trešās daḷas indikatīvā pielikuma 1. e punktu: "[..] pieprasīt patērētājam, kurš nespēj izpildìt savas saistības, maksāt neproporcionāli lielu kompensāciju.” Direktīvas par negodīgiem līguma noteikumiem 3. panta trešā punkta (pielikuma 1. e punkts attiecībā uz neproporcionālu kompensāciju) prasības iestrādātas Patērētāju tiesību aizsardzības likuma 6. panta trešās daḷas ceturtajā punktā [14].

Kopš 2011. gada 1. janvāra ar šo pantu noteikts, ka par netaisnīgiem līguma noteikumiem ir uzskatāmi tādi noteikumi, "kas uzliek patērētājam, kurš neizpilda vai nepienācīgi izpilda līgumsaistības, neproporcionāli lielu līgumsodu vai citu kompensāciju par līgumsaistību neizpildi vai nepienācīgu izpildi salīdzinājumā ar līgumsaistību neizpildīšanas vai nepienācīgas izpildīšanas radīto zaudējumu vai ṇemot vērā citus apstākḷus" [14]. Iepriekšèjā redakcija bija šāda: "[..] uzliek patērētājam, kurš neizpilda līgumsaistības, neproporcionāli lielu līgumsodu." Ši "cita kompensācija par saistību neizpildi", ko likumdevējs faktiski pielīdzinājis līgumsodam, ir tie paši nokavējuma procenti un jebkādi citi kompensācijas veidi. Raugoties uz līgumsodu patērētāju tiesību izpratnē, nav būtiski, ka šis tiesību institūts tiktu saukts tieši šādā vārdā, proti, par līgumsodu. Kā redzams, regulējums attiecas ne vien uz līgumsodu, bet arī uz jebkādām citām kompensācijām, tostarp nokavējuma procentiem.

Patērētāju tiesību aizsardzības likuma jaunajā redakcijā tiek ṇemti vērā arī līgumsaistību neizpildīšanas vai nepienācīgas izpildīšanas radītie zaudējumi. Tas l̦auj secināt, ka patērētāju tiesības ierobežo līgumsoda sodī̌anas funkciju, nedaudz tuvinoties anglosakšu tiesībām raksturīgajai minētā tiesību institūta izpratnei.

Pētot, kā Eiropas Kopienu Tiesa (turpmāk - EKT) raugās uz līgumsoda institūtu Direktīvas par negodīgiem līguma noteikumiem kontekstā, var secināt, ka līgumsods kā netaisnīgs līguma elements visbiežāk sastopams tieši šìs direktīvas izpratnē, piemēram, EKT lietā C-488/11 [21] uz prejudiciālu jautājumu par Direktīvas par negodīgiem līguma noteikumiem 6. panta 1. punkta interpretāciju. Tiesvedībā tika nodots iesniedzējtiesas lūgums par ìres līguma parāda, līgumisko procentu un soda naudas samaksu atbilstoši īres līgumā paredzētajam.

Direktīvas 6. panta 1. punktā noteikts:

"Dalïbvalstis nosaka, ka negodīgi noteikumi, kas izmantoti pārdevēja vai piegādātāja ar patērētāju noslēgtā līgumā, atbilstoši savas valsts tiesību aktiem nav saistoši patērētājam un ka lïgums pie tādiem pašiem noteikumiem turpina pusēm būt saistošs, ja tas var pastāvēt bez negodīgajiem noteikumiem." [5]

Ar šo jautājumu iesniedzējtiesa vēlējās noskaidrot, vai direktīvas 6. pants ir interpretējams tādējādi, ka atbilstoši tam valsts tiesa, kas konstatējusi noteikuma par līgumsodu negodīgumu, tā vietā, lai šo noteikumu nepiemērotu, var samazināt tajā paredzētā līgumsoda apmēru, kā tas atḷauts atbilstoši valsts tiesībām un kā to ir lūdzis patērētājs. EKT savā spriedumā secināja, ka starp profesionāli un patērētāju noslēgtais līgums "pie tādiem pašiem noteikumiem" turpina būt pusēm saistošs, ja tas var pastāvēt "bez negodīgajiem noteikumiem". Vienīgi valstu tiesām ir pienākums novērst negodīga līguma 
noteikuma piemērošanu, lai patērētājam tas nebūtu saistošs, bet tām nav tiesību korigèt tā saturu. Līgumam principā ir jāturpina pastāvēt bez kādiem citiem grozìjumiem, izṇemot negodīgu noteikumu svìtrošanu. Proti, atbilstoši direktīvas 6. panta 1. punktam, ja valstu tiesas konstatē starp profesionāli un patērētāju noslēgta līguma noteikuma par līgumsodu negodīgumu, tās nedrīkst samazināt patērētājam piemērojamā līgumsoda apmēru, tā vietā tiesas attiecīgo līguma noteikumu nepiemēro vispār. Turklāt EKT īpašu uzsvaru liek uz to, ka pašu līgumsoda samērīguma jautājumu Direktīvas par negodīgiem līguma noteikumiem neregulē, to izskata un vērtē nacionālās tiesas pēc savas iniciatīvas.

Ceturtkārt, jāatzīmē arī Eiropas Parlamenta un Padomes 2008. gada 23. aprị̣a Direktīva 2008/48/EK par patēriņa kredītlīgumiem un ar ko atcel Direktīvu 87/102/EEK [6]. Šì direktīva līgumsoda kontekstā jāmin, jo tās atsevišķos pantos noteikts, kāda informācija patērētājam jāsniedz pirms līguma noslēgšanas (5. panta pirmā punkta l. apakšpunktā un 6. panta pirmā punkta i apakšpunktā): "[..] procentus maksājumu kavējumu gadījumā un procedūru to korigéšsanai, un - attiecīgā gadījumā - maksu par saistību nepildīšanu." Tātad šajā direktīvā netiek precizēts, vai līgumsods, kas izriet no minētajiem pantiem, būtu drīzāk zaudējumu atlīdzība vai sods par līguma nepienācīgu izpildī̌anu, vien tajā norādīts, ka informācija par līgumsoda apjomu ir viens no obligātajiem elementiem patēriņa kredìtlīgumos, turklāt to piel̦aujams noteikt gan procentu izteiksmē, gan nemainīgā, konkrētā summā, tādējādi sasaucoties ar Latvijas Civillikuma reglamentēto līgumsoda institūtu.

Pie unifikācijas instrumentiem pieskaita arī dažādus parauglikumus (model law), principus, rekomendācijas un vadlīnijas. Daudzi komersanti, kas darbojas Eiropas Savienības iekšējā tirgū, mūsdienās ievēro Eiropas līgumtiesību principus [30, 359-461]. Šo principu izstrādātāji n,ēmuši vērā galvenokārt Eiropas Savienības dalībvalstu tiesību normas, kā arī citu valstu un starptautiskās tiesības, piemēram, ASV Vienoto tirdzniecības kodeksu [19], Kanādas tiesību idejas, 1980. gada Vīnes konvenciju par starptautiskajiem preču pirkuma un pārdevuma līgumiem [13].

Pie dokumentiem, kuros sistēmiski apvienoti līgumtiesību principi, jāmin arī neatkarīgās starpvalstu organizācijas - Starptautisko privāttiesību institūta (UNIDROIT The International Institute for the Unification of Private Law's) - starptautiskie komerclïgumu principi [36]. UNIDROIT principu mērķis ir regulēt tirdzniecības tiesības visā pasaulē, ne tikai Eiropas Savienībā (atšḳirībā no Eiropas līgumtiesību principiem). UNIDROIT līgumtiesību principi tiek piemēroti arī ārpus Eiropas Savienības, piemēram, ASV. Arī UNIDROIT principiem ir rekomendējošs raksturs, un tie var tikt piemēroti, ja līdzèji par tiem vienojas [24].

Svarīgi ir ne tikai jau nosauktie doktrinārie dokumenti, bet arī Kopējais model̦a projekts (DCFR - Draft Common Frame of Reference jeb Saistibu tiesibu kopëjais modelis) [3]. Tas ir dokuments, kurā apkopoti Eiropas privāttiesību principi, definīcijas un noteikumi. Kopējais modeḷa projekts, pēc tā izstrādātāju domām, varētu kalpot kā paraugs dalībvalstu likumdevējiem. Taču arī šis dokuments nav Eiropas Savienības normatīvs dokuments, un tā trūkums ir milzīgais apjoms, kas droši vien apgrūtinās dalībvalstu likumdevēju iespējas izmantot šo apkopojumu. 
Līgumsoda kontekstā jāakcentē Eiropas Padomes Ministru komitejas 1978. gada 20. janvārī pieṇemtā rezolūcija Nr. (78)3 “Par soda klauzulu civiltiesībās” [31]. Šĩ rezolūcija ir nozīmīga Latvijas civiltiesībās jaunas pieejas dēl līgumsoda aprēḳināšanā, kas izriet no Augstākās tiesas Senāta 2005. gada 26. janvāra sprieduma lietā Nr. SKC-48 par aizdevuma un līgumsoda piedziṇu. Ar Senāta argumentu, ka, "balstoties uz Eiropas Kopienu Tiesas judikatūru, Eiropas Padomes Ministru komitejas rekomendācijai "Par soda klauzulu civiltiesībās" ir netieša un horizontāla iedarbība" [22], turpmāk tiesas visai bieži savā argumentācijā atsaucās uz minēto rezolūciju Nr. (78)3.

Aplūkojot šeit pieminētos aktus - gan ar juridisko spēku apveltìtos, gan dokumentus ar ieteikuma raksturu, var secināt, ka līgumsoda institūts galvenokārt tiek skatìts nevis kā soda mērs, bet gan kā iepriekš novērtēti (vai novērtējami) atlīdzināmie zaudējumi. Aplūkoto tiesību harmonizācijas aktu regulējums neaizliedz par saistību nepienācīgu izpildi piemērot sodoša rakstura līgumsodu, tomēr šis regulējums vairāk līdzinās anglosakšu tiesību saimei raksturīgajam, t. i., izprotot līgumsodu vien kā zaudējumu atlīdzināšanu, un ir pret sodīšanu privāttiesību jomā vispār. Lai skaidrāk izprastu atškiriību starp šiem šķietami līdzīgajiem tiesību institūtiem, jāsalīdzina iepriekš novērtēto zaudējumu atlīdzināšanas un līgumsoda institūts.

\section{Divu klauzulu - iepriekš novērtēto zaudējumu atlīdzināšanas un līgumsoda kā soda - salīdzinājums}

Pastāv būtiska atšḳirība starp dažādās tiesību saimēs atspogụ̣oto līgumsoda institūtu. Fundamentāla atšḳirība par tā izpratni ir kontinentālās Eiropas tiesību sistēmā un anglosakšu tiesību sistēmā. Arī mūsdienās tiesību zinātnieki nespēj rast kompromisu jautājumos par atbildību līgumattiecībās. Daḷa uzskata, ka līgumiskās attiecībās soda sankcijas ir attaisnojamas, savukārt citu nostāja pret tām ir visnotaḷ negatīva.

Vairākumā Eiropas valstu ir pārstāvēta kontinentālās Eiropas tiesību saime. Tā ir Baltijas valstīs, Vācijā, Francijā, Austrijā, Šveicē, Itālijā, Spānijā, Grieḳijā, Portugālē, Beḷgijāā, Nìderlandē, Luksemburgā u. c. Ārpus Eiropas šìs tiesības izplatījušās Tuvo Austrumu valstīs, Dienvidkorejā, Taivānā, Taizemē (saistību tiesību jomā tās tiek dēvētas par "Civilkodeksu valstīm”). Savukārt anglosakšu tiesību saime ir pārstāvēta Anglijā, Velsā, İrijā, Ziemelīirijā, savukārt ārpus Eiropas - ASV (izṇemot Luiziānu), Kanādā (izṇemot Kvebeku), Austrālijā, Jaunzēlandē, Lielbritānijas bijušajās kolonijās u. c.

Pasaulē līgumsods tiek saukts dažādi, piemēram, penalty clause, punitive, exemplary damages, punitive damages - tie visi ir apzīmējumi atrunai par soda naudas izmaksu; turpretī liquidated damages, stipulated payment, stipulated sum, agreed - remedy provision apzīmē iepriekš novērtētu un atrunātu zaudējumus atlīdzinošu summu.

ASV pastāv tikai iepriekš novērtēto zaudējumu atlīdzināšanas institūts, kas paredzēts zaudējumu atlīdzināšanai, un tas tiek piemērots gadījumā, ja tiesa konstatē, ka ar līguma pārkāpumu radītais zaudējums ir grūti aplēšams, taču iepriekš līgumā norunātā 
summa zaudējuma atlīdzināšanai ir samērīga kompensācija gan par esošajiem, gan nākotnē paredzamiem zaudējumiem. Iepriekš novērtēto zaudējumu atlīdzināšanas institūta mērḳis ASV ir grūti pierādāmu un izmērāmu zaudējumu atlīdzināšana. Ja tomēr tiesa konstatē, ka iepriekš norunāto zaudējumu atruna ir nesamērīgi augsta pret zaudējumiem, kas izriet no līguma pārkāpuma, šì atruna tiek uzskatìta par spēkā neesošu un pusei, kas cietusi no līguma pārkāpuma, ir tiesības prasìt tikai atlīdzību par faktiskajiem zaudējumiem $[27,1-7]$.

Iepriekš novērtēto zaudējumu atlīdzināšanas klauzulu izskatî̌ana ASV jurisdikcijā ir atškirīga, tomēr parasti tiesas, skatot, vai šì klauzula tiek izpildìta, vērtē divus aspektus. Viens no šiem aspektiem ir nenoteiktības elements, proti, vai ar līguma pārkāpumu radīto kaitējumu ir grūti noteikt. Otrs - pamatotība, proti, vai iepriekš novērtēto zaudējumu atlīdzināšanas summa ir pamatota proporcionāli faktiskajiem vai nākotnē sagaidāmajiem zaudējumiem, kas izriet no līguma pārkāpuma. Ja tā nav, tad minētais tiesību institūts tiek uzskatīts par sodu, kas ir prettiesisks ASV privāttiesību jomā, un tādējādi iepriekš novērtēto zaudējumu atlīdzināšanas klauzula nav piemērojama [29, 656-659].

Citās valstīs, kurās ir paražu tiesības, piemēram, Lielbritānijā, İrijā, Austrālijā un Kanādā, ir līdzīgi noteikumi saistībā ar iepriekš novērtēto zaudējumu atlīdzināšanas institūtu, kuru ir aizliegts izmantot sodīšanas nolūkā. Iznēemums ir Indijas līgumtiesības, kurās Līgumu likums nenošķir iepriekš novērtēto zaudējumu atlīdzību un līgumsodu. Lìgumsodu šeit aț̣auts piedzìt no līgumu pārkāpušās puses pat gadījumā, ja tā funkcija ir sodìt līguma pārkāpēju [10].

Ja zaudējumu atlīdzināšanas institūts balstìts uz nosacỉjumu, ka līgumsaistību neizpildes vai nepienācīgas izpildes gadījumā ir nodarīi faktiski un pierādāmi zaudējumi, kas jāatlīdzina, tad, lai îstenotu soda klauzulu, nav nepieciešams zaudējumu pierādīšanas fakts.

Pētot dažādu valstu, kurās atzīst līgumsodu kā soda klauzulu, civilkodeksus, var secināt, ka tajos atspogulotas Eiropas Padomes Ministru komitejas 1978. gada 20. janvāra rezolūcijas (78)3 "Par soda klauzulu civiltiesībās" rekomendācijas [27, 1-7]. Piemēram, Igaunijas Saistỉbu tiesību 162. pantā [18], Vācijas Civilkodeksa 343. pantā [9] un Nīderlandes Civilkodeksa 6:94. panta 1. daḷā [17] ḷauts tiesām pèc puses lūguma samazināt līgumsodu, ja tas ir pārmērīgs, un Lietuvas Civillikumā - arī gadījumā, ja saistība jau daḹèji izpildīta [12]. Līgumsodu samazināt samērā ar pienākuma neizpildes sekām ḷauts arī atbilstīgi Francijas Civilkodeksa 1152. pantam [16].

Savukārt Itālijā saistību tiesībās tiek atzīta gan zaudējumu atlīdzināšana, gan soda klauzula, taču tās pastāv vien tiesību doktrīnā, nevis Civilkodeksā. Itālijas saistību tiesībās līgumsods kā soda sankcija tiek piel̦auts, taču tiesa to var samazināt, ja tas ir pārmērīgs vai ja puse izpildijjusi galveno saistību [28, 309-326].

Spānijas Civilkodeksa 1154. pantā noteikts, ka tiesnesis objektīvi var mainīt līgumsoda lielumu, taču tikai gadījumā, ja parādnieks savas saistības ir pildījis (daḷēji vai neregulāri) [15]. Spānijas Civilkodekss ir viens no retajiem, kas noškị, vai līgumu pārkāpusi juridiska vai fiziska persona. Arī šis apstāklis tiesā, izskatot līgumsoda samazināšanas 
pamatu, tiek nnemts vērā. Jāpiemin, ka Spānija ir viena no retajām valstīm, kas nav veikusi grozījumus Civilkodeksā, l̦aujot tiesai samazināt līgumsodu vien tādēl, ka tas ir pārmērīgs $[25,100-103]$.

Spānijas doktrīnā, līdzīgi kā Francijas doktrīnā, tiek diskutēts par iespēju ieviest fiksētu, iepriekš norunātu summu par līguma laušanu neatkarīgi no tā, vai tā būtu zaudējumu atlīdzināšana vai līgumsods. Atškirinibā no Latvijas doktrīnas šajās diskusijās tiek minēta nesamērīgi maza iepriekš norunātā summa par līguma laušanu, proti, Francijas un Spānijas praksē acīmredzot biežāk sastopama problēma, ka līgumā, nosakot pārāk mazu līgumsodu, nolīgtā neizpildes gadỉjumā zaudējumus cieš tieši kreditors [25, 100-103]. Un šajā sakarā, atsaucot atmiṇā Latvijas Civillikuma 2013. gada 20. jūnija grozījumus, iespējams, jaunajā regulējumā tiks noteikts, ka atsevišķos gadījumos kreditors var nokḷūt neizdevīgā ekonomiskā situācijā, ja parādniekam par nepienācīgu līguma izpildi jāmaksā maksimums - $10 \%$ no pamatparāda vai galvenās summas, lai arī kreditora zaudējumi no šādas nepienācīgas izpildes varētu krietni pārsniegt šo 10 \% līgumsoda slieksni. Piemēram varētu minēt būvniecības jomu.

Šveices tiesiskais regulējums ir visai līdzīgs Vācijas un Nĩderlandes regulējumam, kas tiesai ḷauj samazināt līgumsodu, ja tas ir acīmredzami pārmērīgs. Šveices Civilkodeksā reglamentēta tiesas tiesība samazināt līgumsodu, ja tas ir pārmērīgs [25, 100-103].

Skandināvijas valstu - Dānijas, Norvēgijas un Zviedrijas - tiesiskais regulējums l̦auj tiesām mainīt līgumsoda lielumu, ja tās uzskata to par nepamatotu, vai pat līgumsodu pilnībā atcelt [27, 1-7]. Piemēram, Zviedrijas Tirdzniecības kodeksā tiek diferencētas gan līguma slēdzēja puses - vājāko un stiprāko līdzēju - līgumsoda piemērošanas jautājumos, gan, aizsargājot kādu pusi, tiek ņemti vērā īpaši apsvērumi. Tādējādi saskatāma līdzība ar Igaunijas, Vācijas un Spānijas tiesību normām, kurās ṇemts vērā pušu ekonomiskais stāvoklis, likumīgās intereses un tiesiskais statuss.

Arī Beḷgijas Augstākā tiesa ir noteikusi, ka iepriekš norunātais maksājums zaudējumu atlīdzināšanai, kurš bijis spēkā, slēdzot līgumu, bet laika gaitā zaudējis savu zaudējumu atlīdzināšanas funkciju, kḷūstot par sodīšanas līdzekli, ir atceḷams. Arī citos gadījumos iepriekš līgumā norunātais maksājums ir samazināms, ja tas uzskatāms par acīmredzami nesamērīgu, salīdzinot ar saistību neizpildes sekām [30, 456].

Citas valstis, kurās ir civillikums un kuras ir ārpus Eiropas, arī ir pārṇēmušas līdzīgu pieeju līgumsodu samērīguma regulēšanā. Kinnas Tautas Republikas Līgumtiesību likumā (turpmāk - K,TR Līgumtiesību likums) paredzēti trīs veidu tiesiskās aizsardzības līdzekḷi - līguma turpmāka izpildīšana neatkarīgi no zaudējumu atlīdzināšanas, zaudējumu atlīdzināšana un līgumsods. KTRR Līgumtiesību likuma 114. pantā noteikts, ka līguma slēdzējas puses var vienoties par noteiktu summu, ko maksā līgumu pārkāpusī puse. Tāpat puses var vienoties par zaudējumu atlīdzỉbu, ko maksā otrai pusei līgumu pārkāpusī puse, n,emot vērā pārkāpuma smagumu. Puses var noteikt arī metodi, kā aprēkināt atlīdzību par zaudējumiem, kas radušies līguma pārkāpuma dēḷ. Turklāt likumā noteikts: ja iepriekš ar līgumu noteiktā summa ir mazāka par zaudējumiem, kas izriet no līguma pārkāpuma, cietusī puse var sniegt Tautas tiesā vai škīiējtiesā lūgumrakstu ar 
lūgumu palielināt līgumsoda lielumu. Attiecīgi, ja līgumā noteiktais līgumsods pārsniedz zaudējumus, kas izriet no līguma pārkāpuma, Tautas tiesa vai šḳirējtiesa ir tiesīga to samazināt. Ja puses līgumā ir noteikušas līgumsodu par novēlotu līgumsaistību izpildi, tai pusei, kas pārkāpusi līgumu, ir ne vien pienākums samaksāt līgumsodu, bet arī izpildīt līgumsaistības [4]. Līguma turpmāka izpildījuma pieprasīšana nozīmē, ka cietusī puse otrai pusei var prasìt līguma turpmāku izpildī̌sanu, ja izpildīšana joprojām ir iespējama. Tādējādi šāda prasība ir savā ziṇā pielīdzināma sankcijai, jo tā vairs nav tas pats, kas brīvprātīgs izpildījums. Šādas nepārtrauktas darbības mērḳis ir konkrētas darbības vai faktisko darbību rezultāts. Šāda nepārtraukta darbība ir traktējama kā juridisks pienākums, proti, sankcija. Maksājumu saistībās ir prasība obligāti izpildīt līgumu [26, 12].

Līdzīgi kā anglosakšu tiesību saimi pārstāvošajās valstīs, arī Ǩinā īpaši netiek atzīta līgumsoda sodīšanas funkciju. Atškiriībā no faktisko zaudējumu atlīdzināšanas institūta (valstīs, kurās ir paražu tiesības, pazistama kā damages) K,TR Līgumtiesību likums reglamentē arī tiesību institūtu, kura galvenā pazīme ir paredzamība (iepriekš aprēḳinātie zaudējumi, potenciālie zaudējumi, kas rodas laika gaitā, pakāpeniski - liquidated damages, kā valstīs, kurās ir paražu tiesības). Lìguma slēdzēja puses līgumā var brīvi vienoties par šo abu lïgumsodu veidu lielumu, bet tas ar likumu ir aprobežots ar zaudējumu un iespējamo zaudējumu lielumu, kas radies nepienācīgas līguma izpildes dēḷ. Nav spēkā tādi līgumsodi (ĶTR Līgumtiesību likumā saukti par zaudējumu atlīdzināšanu), kam ir tikai sodīšanas funkcija.

Ir visai sarežgìiti rast vienādu līgumsoda regulējumu Eiropas (un ne tikai) valstīs. Atškiras pat to piemērošanas pamatmērḳi - zaudējumu atlīdzināšana vai sods. Vairāku valstu tiesas nekad nav vērtējušas, vai līgumā noteiktais līgumsods vērtējams kā sods. Proti, tiesas nenošḳir zaudējumu atlīdzināšanas institūtu no līgumsoda ar sodīšanas funkciju institūta. Tās vērtē vien to, vai piemērošana ir tiesiska un vai sods nav pārmērīgs, salīdzinot ar zaudējumiem līguma neizpildes dēḷ. Šāda pieeja ir visai tuva anglosakšu pieejai līgumsodu samērīguma regulēšanā.

Salīdzinot zaudējumu atlīdzināšanas un līgumsoda (kā sankcijas) izpausmes, var secināt, ka nevienā no pētāmajām valstīm netiek noliegta zaudējumu atlīdzināšanas klauzula (gan iepriekš novērtētā, gan faktiskā). Tomēr tiesas vērš uzmanību arī uz šī tiesību institūta samērīgumu attiecībā pret zaudējumiem, kas ir vai var rasties līguma nepienācīgas izpildes dēḷ. Savukārt līgumsodu kā sankciju neatzīst nevienā anglosakšu tiesību saimes jeb precedentu tiesību valstī, tāpat kā dạ̦ā t. s. civilkodeksu valstu. Joprojām zinātnieki diskutē par un pret līgumsodu kā saistību pastiprināšanas līdzekli, kā draudu pret nelabvēlīgām sekām līguma pārkāpuma gadījumā. Bieži vien tiesību zinātnieki, kas nostājas pret līgumsodu kā sodīšanas instrumentu, norāda, ka tā noteikšana līgumā var veicināt nevis līguma izpildi, bet, gluži pretēji - tā neizpildi, ja līguma izpildī̌̌anas pienākums ir smagāks par līgumsoda samaksu [29, 659-661]. Šādām bažām ir pamats, jo īpaši ṇemot vērā, ka Civillikumā tiek ierobežots līgumsoda lielums. Tas var provocēt situācijas, kurās līguma slēdzējam ir vienkāršāk samaksāt līgumsodu par saistību neizpildi, atstājot otru līguma slēdzēju ekonomiski neizdevīgā situācijā. Ķinā likumiskā spēkā ir viens tiesiskās aizsardzības līdzeklis, kas varētu atrisināt šo situāciju, - līguma turpmākas 
izpildīšanas pieprasī̌̌ana, ja vien tas ir iespējams. Tomēr citviet pasaulē šādu tiesiskās aizsardzības līdzekḷ nav. Vairāki tiesību zinātnieki uzsver, ka bieži vien ir tā, ka iepriekš novērtētie zaudējumi nav pietiekami, lai segtu visus reālos un nākotnē paredzamos zaudējumus pusei, kura cietusi no līguma nepienācīgas izpildes.

Aplūkojot dažādu valstu praksi līgumsodu piemērošanā un n̦emot vērā Civillikuma jauno līgumsoda regulējumu, saistībā ar līgumsoda aprobežošanu Latvijas saistību tiesībās var saskatīt vairākus problēmjautājumus.

1. Jautājums par saistības vērtības noteikšanu. Piemērs: beztermiṇa līgums ar periodiskiem maksājumiem. Kā noteikt līguma vērtību, no kuras jāizriet līgumsodam?

2. Līgumsoda samērīguma jautājums. Piemērs: līgumsods par saistību neizpildi termiņā ir aprobežots ar 10\% no pamatparāda vai galvenās saistỉbas, taču likumā nav noteikts, par cik ilgu kavējumu kreditors var prasit līgumsodu pilnā apmērā, proti, vai visus $10 \%$ no līguma summas kreditors drīkst prasīt arī par vienas dienas kavējumu. Vai šādos apstākḷos līgumsods būs samērīgs?

3. Kas jāsaprot ar jēdzienu "galvenā saistība"? Piemērs: par līgumu, kas noslēgts uz gadu, pasūtītājs par pakalpojumu maksā mēnesi uz priekšu. Gadỉjumā, ja pasūtìtājs kavē maksājumu, kas būtu uzskatāms par galveno saistību - visa atlikusī, nesamaksātā summa vai ikmēneša maksājuma summa?

Otrs problēmjautājumu loks - kā nošḳirt saistību neizpildi vispār no saistību nepienācīgas izpildes vai neizpildes noteiktā laikā? Lai paskaidrotu, kāpēc šo faktoru nodalīšanā var rasties grūtības, ilustrācijai noderēs daži piemēri.

1. Lìgums starp pusēm tiek noslēgts uz diviem gadiem. Lìgumā paredzētas vienas puses vienpusējas tiesības izbeigt līgumu pirms termiṇa, samaksājot par to vienreizēju līgumsodu. Mēnesi pēc līguma noslēgšanas viena puse vienpusēji lauž līgumu. Vai šajā situācijā ir saistību neizpilde vispār vai nepienācīga izpilde (t. i., neizpildīšana īstajā laikā)?

2. Starp pusēm tiek slēgts līgums par terminētu preces piegādi. Prece tiek piegādāta termiṇā, taču tā ir ar trūkumiem. Kā saistība būtu traktējama šajā gadījumā - kā neizpildīta vispār vai nepienācīgi izpildīta termiṇā?

N̦emot vērā iepriekš aplū kotos problēmjautājumus, varētu šḳist, ka globālā mērogā līgumsods tiek pietuvināts anglosakšu tiesību saimes valstīm raksturīgai iepriekš novērtēto zaudējumu atlīdzināšanai, tomēr netrūkst piemēru, ka arī anglosakšu tiesību saimes valstī Lielbritānijā skatījums uz šo tiesību institūtu nav tik viennozīmīgs. Piemēram, jāieskatās sen - 1914. gadā - Apvienotās Karalistes Lordu palātā izskatītā lietā Dunlop Pneumatic Tyre Company Limited $v$ The New Garage and Motor Company Limited [20], kas pēc simts gadiem kḷuvusi aktuāla Anglijas un Velsas Augstākajā tiesā iepriekš novērtēto zaudējumu atlīdzināšanas klauzulas un soda klauzulas kontekstā. Dunlop Tyres noslēdza līgumu ar New Garage Company par preču (riepu pārsegu un cauruḷu) piegādi. Ar šo līgumu New Garage Company apṇēmās nepārdot minētās preces saviem klientiem par zemāku cenu, nekā ražotājs noteicis. Līguma 5. punktā noteikts, ka New Garage Company apṇemas par līguma pārkāpšanu maksāt Dunlop Tyres piecas Lielbritānijas 
sterliṇu mārcinas par katru riepas pārsegu un cauruli, kas tiktu pārdota, pārkāpjot līgumu. Vēlāk Dunlop Tyres konstatēja, ka New Garage Company pārdevusi riepu pārsegus un caurules, kas nebija saskaṇā ar aktuālo Dunlop Tyres noteikto cenrādi, tādējādi Dunlop Tyres cēla prasību tiesā, prasot zaudējumu atlīdzināšanu no New Garage Company.

Tiesā tika vērtēts, vai piecas mārciṇas ir traktējamas kā iepriekš novērtēto zaudējumu atlīdzinājums vai līgumsods, t. i., kā soda nauda (sankcija). Zemākās instances tiesa lēma, ka piecas mārcinas jātraktē kā zaudējumu atlīdzinājuma summa un tā ir piedzenama no New Garage Company. Turpretim apelācijas instances tiesa sprieda, ka minētā summa ir drīzāk soda nauda, nevis iepriekš novērtētie zaudējumi, kas varētu rasties nākotnē negūtu ienākumu veidā, tādēl apelācijas instances tiesa lēma, ka Dunlop Tyres var saṇemt lïdzekḷus tikai par faktiskajiem zaudējumiem. Dunlop Tyres šo lēmumu pārsūdzēja, un lieta nonāca Augstākajā tiesā. Lordu palāta, izskatot lietu, saskārās ar jautājumu par faktiskajiem zaudējumiem un iepriekš novērtētajiem zaudējumiem, kas saistāmi ar iespējamiem nākotnes zaudējumiem, tāpat ar jautājumu, vai līgumā noteiktā summa - piecas mārciņas - ir drīzāk iepriekš novērtēti zaudējumi par negūtajiem ienākumiem līguma pārkāpuma rezultātā vai nelabvēlīgu seku draudi, ko Apvienotās Karalistes saistību tiesības neatzīst, tādējādi nodemonstrējot, cik sarežğîti dažkārt var būt nošḳirt zaudējumu atlīdzināšanas klauzulu no soda klauzulas [20].

Pēc simts gadiem - 2015. gadā - Apvienotajā Karalistē Augstākā tiesa pārskatīja likumu par soda klauzulām. 2015. gadā, izvērtējot minēto lietu, Anglijā un Velsā likums joprojām bija pret soda klauzulu piemērošanu, taču likumā vairs nav vispārējas prasības par iepriekšēju finanšu zaudējumu aplēsi, slēelzot līgumu, kurus varētu ciest līguma slēdzēja puse, otrai pusei pārkāpjot līgumu [32].

Pēc Dunlop Tyres v New Garage Company lietas var secināt, ka ne katrā līgumā iespējams paredzēt un iepriekš novērtēt visus potenciālos zaudējumus līguma nepienācīgas izpildes dēl, jo īpaši - netiešos zaudējumus, kas varētu rasties negūtu ienākumu veidā. Tādējādi redzams, ka ne vien kontinentālās Eiropas tiesību līgumsods tiek pietuvināts anglosakšu iepriekš novērtēto zaudējumu atlīdzināšanas institūtam, bet arī anglosakšu iepriekš novērtēto zaudējumu institūtam ir nepilnības, kas l̦auj to pietuvināt soda klauzulai.

Lai gan literatūrā par līgumsaistībām, kurā analizēti ekonomiskie procesi, visai bieži valda akadēmiska vienprātība par līgumsodu sodošo dabu, aizvien biežāk parādās diskusijas par to, kā nošķirt šĩ institūta sodošo dabu no zaudējumu atlīdzinošās dabas. Visai bieži, kā piemērā ar Dunlop Tyres v New Garage Company lietu, šì robeža var būt diezgan trausla un grūti identificējama. Galvenais arguments tiesību doktrīnā par labu līgumsodu sodošajai funkcijai ir tas, ka iepriekš novērtēto zaudējumu atlīdzināšanas institūts ne vienmēr pilnībā izpilda savu galveno, proti, kompensējošo funkciju, atstājot vienu no līdzējiem ekonomiski neizdevīgā pozīcijā. Turklāt, dažu autoru skatījumā, līgumsodu ir daudz vienkāršāk piedzīt, jo iepriekš novērtēto zaudējumu atlīdzināšanas institūts būtiski sarežğì līgumus un līguma pārkāpumu gadījumā nereti rodas jauni strīdi. Tāpat tiesību doktrīnā kā arguments par labu līgumsoda sodošajai dabai tiek nosaukts jau agrāk šeit 
pieminētais līgumu slēgšanas brīvības princips. Tomēr jāuzsver, ka šo nevar uzskatīt par visai pārliecinošu argumentu, jo līgumu slēgšanas brīvība tomēr nevienās civiltiesībās nav absolūta un tāda nedrīkstētu būt arī saistību tiesībās.

Salīdzinot līgumsodu iepriekš novērtēto zaudējumu atlīdzināšanas izpratnē un līgumsodu sankcijas izpratnē, var secināt, ka šie divi šḳietami līdzīgie, tomēr visai atšṣirīgie tiesību institūti ne vienmēr ir vienkārši nošķirami, īpaši tādēl, ka tie laika gaitā tiek pietuvināti viens otram, padarot robežškirtni starp tiem aizvien sarežg̀itāk saskatāmu un nodalāmu.

\section{Secinājumi}

1. Līgumsoda evolūciju Latvijā ir ietekmējusi globalizācija, kas saistīta ar geogrāfisko robežu izzušanu, tādējādi saasinot problēmas, tostarp par saistību izpildi un līgumsoda piemērošanu.

2. Kontinentālās Eiropas tiesību sistēmā un anglosakšu tiesību sistēmā līgumsods ir tas tiesību institūts, par kuru izpratne kardināli atšḳiras, jo anglosakšu tiesībās kategoriski netiek atzìts jēdziens "līgumsods", tāpēc ka privāttiesības nevar būt saistītas ar sodīšanu, turpretim kontinentālās Eiropas tiesībās tas ir pavisam normāls tiesību institūts.

3. Starptautiskajos tiesību aktos - gan ar juridisko spēku, gan ar ieteikuma raksturu - līgumsods ir skatīts nevis kā soda mērs, bet gan kā iepriekš novērtētie (vai novērtējamie) atlīdzināmie zaudējumi. Aplūkoto tiesību harmonizācijas aktu regulējums neaizliedz piemērot sodoša rakstura līgumsodu par saistību nepienācīgu izpildi, tomēr šis regulējums vairāk līdzinās anglosakšu tiesību saimei raksturīgajam, kas saistìts vien ar zaudējumu atlīdzināšanu.

4. Ja zaudējumu atlīdzināšanas institūts balstìts uz nosacỉjumu, ka līgumsaistību neizpildes vai nepienācīgas izpildes gadījumā ir nodarìti faktiski un pierādāmi zaudējumi, kas ir jāatlīdzina, tad, istenojot soda klauzulu, nav nepieciešams zaudējumu pierādišanas fakts.

5. Kopš Civillikuma 2013. gada 20. jūnija grozïjumiem līgumsoda kontekstā atklājas atseviški ar to saistīti neatbildèti jautājumi:

- Kā noteikt saistības vērtību?

- Par cik ilga perioda kavējumu līgumsodu var prasīt maksimālā - likumā noteiktā - apmērā, lai tas būtu uzskatāms par samērīgu?

- Kas saprotams ar jēdzienu "galvenā saistība"?

- Kā nošķirt saistību neizpildi vispār no saistību nepienācīgas izpildes vai neizpildes noteiktā laikā?

6. Salīdzinot līgumsodu iepriekš novērtēto zaudējumu atlīdzināšanas izpratnē un līgumsodu sankcijas izpratnē, var secināt, ka šie divi šḳietami līdzīgie, tomēr visai atšḳirīgie tiesību institūti ne vienmēr ir vienkārši nošḳirami. Laika gaitā tie ir pietuvināti viens otram, padarot robežškirtni starp tiem aizvien sarežğîtāk saskatāmu un nodalāmu. 


\section{Impact of Globalisation on the Application of the Contractual Penalty}

\section{Abstract}

The article provides an insight into the nature of the contractual penalty. It aims, by exploring a contractual penalty institute on a global scale, to reveal problems related to the application contractual penalty in current legal environment. In the context of the contractual penalty institute, a priority shall be the issue of applying proportionality principle on a national and global scale. The article compares the understanding of the contractual penalty in various legal systems and the impact of globalisation on the contractual penalty institute in the Republic of Latvia.

Keywords: contractual penalty, penalty clause, liquidated damages.

\section{Avoti un literatūra}

\section{Tiesību akti}

1. Civillikums: Latvijas valsts likums: stājas spēkā 01.09.1992. Valdības Vēstnesis. 41, 20.02.1937. Konsolidētā redakcijā iegūts no: https://likumi.lv/doc.php?id=225418 [sk. 03.04.2018.].

2. Civilprocesa likums: Latvijas Republikas likums: stājas spēkā 01.03.1999. Latvijas Vēstnesis. 326/330(1387/1391), 03.11.1998. Konsolidētā redakcijā iegūts no: https:/likumi.lv/doc. php?id=50500 [sk. 03.04.2018.].

3. Consumer Contracts Law: Principles, Definitions and Model Rules of European Private Law. Draft Common Frame of Reference (DCFR). European Comission. Iegūts no: http://ec.europa. eu/justice/contract/files/european-private-law_en.pdf [sk. 07.04.2018.].

4. Contract Law of the People's Republic of China (Adopted and Promulgated by the Second Session of the Ninth National People's Congress March 15, 1999): KTR likums. Iegūts no: http://www. wipo.int/edocs/lexdocs/laws/en/cn/cn137en.pdf [sk. 07.04.2018.].

5. Eiropas Padomes 1993. gada 5. aprīḷa Direktīva 93/13/EEK par negodīgiem noteikumiem patērētāju līgumos. Eiropas Savienïbas Oficiālais Vēstnesis. L95/29, 21.04.1993.

6. Eiropas Parlamenta un Padomes Direktīva 2008/48/EK par patērina kredïtlīgumiem un ar ko atcel Direktīvu 87/102/EEK: pieñemta 23.04.2008. Eiropas Savienïbas Oficiālais Vēstnesis. L133/66, 22.05.2008.

7. Eiropas Parlamenta un Padomes 2011. gada 16. februāra Direktīva 2011/7/ES par maksājumu kavējumu novēršanu komercdarïjumos, dokuments attiecas uz EEZ. Oficiālais Vēstnesis. L48/1, 23.02.2011.

8. Federal Act on the Amendment of the Swiss Civil Code (Part Five: The Code of Obligations): Šveices likums. Iegūts no: https://www.admin.ch/opc/en/classified-compilation/19110009/201704010000/220.pdf [sk. 07.04.2018.].

9. German Civil Code BGB (Bürgerliches Gesetzbuch): Vācijas likums. Iegūts no: https://www. gesetze-im-internet.de/englisch_bgb/ [sk. 26.10.2017.]. 
10. Indian Contracts Act: Indijas likums. Iegūts no: http://www.advocatekhoj.com/library/bareacts/ indiancontract/74.php?Title=Indian\%20 Contract\%20Act,\%201872\&STitle=Compensation\%20 for\%20breach\%20 of\%20 contract\%20where\%20penalty\%20stipulated\%20for [sk. 20.10.2017.].

11. Krievijas Civilkodekss (ГражАанский кодекс Российской Федерации): Krievijas Federācijas likums. Iegūts no: https://www.consultant.ru/document/cons_doc_LAW_5142/ [sk. 26.10.2017.].

12. Lietuvas Civilkodekss (Civilinis kodeksas): Lietuvas likums. Iegūts no: http://tm.infolex. lt $/$ ?item=taktai_list\&aktoid=50805\&strnr=6.73 [sk. 26.10.2017.].

13. Par Apvienoto Nāciju Organizācijas Konvenciju par starptautiskajiem preču pirkuma-pārdevuma līgumiem. Latvijas Vēstnesis. 170(885), 03.07.1997.

14. Patērētāju tiesību aizsardzības likums: Latvijas Republikas likums: stājas spēkā 15.04.1999. Latvijas Vēstnesis. 104/105(1564/1565). Konsolidētā redakcijā iegūts no: https://likumi.lv/doc. php?id=23309 [sk. 03.04.2018.].

15. Spanish Civil Code: Spānijas likums. WIPO. Iegūts no: http://www.wipo.int/wipolex/en/text. jsp?file_id=221320 [sk. 26.10.2017.].

16. The Civil Code of the France (Le Code civil des Français): Francijas likums. Iegūts no: https://www. legifrance.gouv.fr/affichCode.do?cidTexte=LEGITEXT000006070721\&dateTexte $=20080225$ / [sk. 26.10.2017.].

17. The Civil Code of the Netherlands (Burgerlijk Wetboek): Nìderlandes likums. Dutch Civil Law. Iegūts no: http://www.dutchcivillaw.com/civilcodebook066.htm [sk. 26.10.2017.].

18. The Law of Obligations Act (Võlaõigusseadus): Igaunijas likums. Riigi Teataja. Iegūts no: https:// www.riigiteataja.ee/en/eli/506112013011/consolide [sk. 26.10.2017.].

19. USA Uniform Commercial Code: ASV likums. Legal Information Institute. Iegūts no: https:// www.law.cornell.edu/ucc [sk. 07.04.2018.].

\section{Tiesu prakse}

20. Dunlop Pneumatic Tyre Company Limited v The New Garage and Motor Company Limited 01.07.1914. Doyles. 2005. Iegūts no: https://mosaicprojects.com.au/casewatch/1034\%20 Dunlop\%20v\%20New\%20Garage.pdf [sk. 07.04.2018.].

21. Eiropas Savienības Tiesas spriedums 13.05.2013. lietā C-488/11. Iegūts no: http://curia.europa. eu/juris/document/document.jsf?text=1\%25C4\%25ABgumsods\&docid=137830\&pageIndex=0\& doclang=LV\&mode=req\&dir=\&occ=first \&part=1\&cid=1453608\#ctx1 [sk. 07.04.2018.].

22. Latvijas Republikas Augstākās tiesas Senāta 2005. gada 26. janvāra spriedums lietā Nr. SKC-48. Jurista Vārds. 14(369), 19.04.2005.

\section{Literatūra}

23. Brīvmanis, V. 1939. Lìgumsods. Rìga.

24. Broka, B. UNIDROIT Starptautiskie komerclīgumu principi 2010. Iegūts no: https://www.google. lv/url?sa=t\&rct=j\&q=\&esrc $=$ s\& source=web\&cd=2\&ved=0ahUKEwiGh6i5uu3WAhVGQJoKHdp bD0UQFggrMAE\&url=https\%3A\%2F\%2Fwww.tm.gov.lv\%2Ffiles\%2Farchieve\%2Flv_jaunumi_B_ Broka.pdf\&usg=AOvVaw2YU89_ubfTwhdoMzBb5PQb [sk. 07.04.2018.].

25. García, I. M. 2012. Enforcement of Penalty Clauses in Civil and Common Law: A Puzzle to be Solved by the Contracting parties. European Journal of Legal Studies. 5(1), 100-103.

26. Leng, J., Shen, W. 2016. The Evolution of Contract Law in China: Convergence in Law but Divergence in Enforcement. Cambridge: Cambridge University Press. 17.01.2017. 
27. McKenna, J. F. 2008. Liquidated Damages and Penalty Clauses: A Civil Law versus Common Law Comparission. ReedSmith. Spring, 1-7.

28. Patti, F. P. 2015. Penalty Clauses in Italian Law. Kluwer Law International. Iegūts no: https:// www.academia.edu/29374462/Penalty_clauses_italian_law?auto=download [sk. 07.04.2018.].

29. Pressman, M. 2013. The Two-Contract Approach to Liqudated Damages: a New Framework for Exploring the Penalty Clause Debate. Virginia Law E Business Review. 7, Spring, 656-659.

30. Principles of European Contract Law. Parts I and II. Combined and revised. Prepared by The Commision of Contract Law Chairman: Professor O. Lando. Ed. by O. Lando and H. Beale. The Hague, London, Boston: Kluwer Law International, 2000.

31. Relating to penal clauses in civil law: Resolution (78)3, adopted by the Committee of Ministers on 20 January 1978. Iegūts no: https://rm.coe.int/CoERMPublicCommonSearchServices/Disp layDCTMContent?documentId=0900001680505599 [sk. 07.04.2018.].

32. Roberton, M. 2017. In terrorem "Penalty clauses" in contracts - the Scottish Law Commission review. Mitchells Roberton. Iegūts no: http://www.mitchells-roberton.co.uk/bullet-point-update/ february-2017-in-terrorem-penalty-clauses-in-contracts-the-scottish-law-commission-review/ [sk. 30.10.2017.].

33. Tiesu prakse līgumsodu piemērošanā. Latvijas Republikas Augstākā tiesa, Senāta Civillietu departaments, 2013.

34. Torgāns, K. Līgumsods nosakāms konkrētā summā. Jurista Vārds. 4(755), 29.01.2013.

35. Torgāns, K. 2013. Lìgumu un deliktu tiesību problēmas. Rīga: Tiesu namu aǵentūra.

36. UNIDROIT Principles of International Commercial Contracts 2016. Iegūts no: https://www. unidroit.org/instruments/commercial-contracts/unidroit-principles-2016 [sk. 07.04.2018.]. 